\title{
SEED FERNS SURVIVED THE END-CRETACEOUS MASS EXTINCTION IN TASMANIA ${ }^{1}$
}

\author{
Stephen McLoughlin, ${ }^{2,6}$ Raymond J. Carpenter, ${ }^{3}$ Gregory J. Jordan, ${ }^{4}$ \\ AND ROBERT S. HILL ${ }^{3,5}$
}

\begin{abstract}
${ }^{2}$ Paleobotany Department, The Swedish Museum of Natural History, Box 50007 SE-104 05 Stockholm, Sweden; ${ }^{3}$ School of Earth and Environmental Sciences, University of Adelaide, Adelaide, South Australia 5005, Australia; ${ }^{4}$ School of Plant Science, University of Tasmania, Private Bag 55, Hobart, Tasmania 7001, Australia; and ${ }^{5}$ Centre for Evolutionary Biodiversity, South Australian Museum, Adelaide, South Australia 5000, Australia
\end{abstract}

\begin{abstract}
Seed ferns, dominant elements of the vegetation in many parts of the world from the Triassic to Cretaceous, were considered to have disappeared at the end of the Cretaceous together with several other groups that had occupied key positions in terrestrial and marine ecosystems such as dinosaurs, plesiosaurs, and ammonoids. Seed-fern demise is generally correlated with competition from diversifying flowering plants through the Cretaceous and the global environmental crisis related to the Chicxulub impact event in the paleotropics at the end of the period. New fossils from Tasmania show that one seed-fern lineage survived into the Cenozoic by at least 13 million years. These fossils are described here as a new species, Komlopteris cenozoicus. Komlopteris is a genus of seed ferns attributed to Corystospermaceae and until now was not known from sediments younger than the Early Cretaceous. Discovery of this "Lazarus taxon," together with the presence of a range of other relictual fossil and extant organisms in Tasmania, other southern Gondwanan provinces, and some regions of northern North America and Asia, underscores high-latitude regions as biodiversity refugia during global environmental crises and highlights their importance as sources of postextinction radiations.
\end{abstract}

Key words: Australia; Corystospermaceae; Eocene; extinction; Komlopteris; refugia; seed ferns; Tasmania.

Mesozoic seed ferns (pteridosperms) constitute a loosely defined and probably paraphyletic group comprising, in its broadest sense, Peltaspermales, Caytoniales, Corystospermales, Bennettitales, Pentoxylales, and several other extinct gymnosperms with variably enclosed or cupulate, seed-bearing organs. These trees and shrubs typically combined superficially fernlike foliage with angiosperm-like innovations for ovular protection. Their sophisticated reproductive structures have long aroused botanical interest as potentially signifying close affiliations with flowering plants. However, the relationships among seed-fern clades and with other seed plants remain unclear (Doyle, 2006).

The relative importance of seed ferns in the terrestrial flora is comparable to that of dinosaurs in the terrestrial fauna and of plesiosaurs and ammonites in the marine realm. Seed ferns were diverse, abundant, and cosmopolitan in early to mid-Mesozoic floras and probably exceeded conifers in terms of vegetation dominance in many regions (Vakhrameev, 1991; Rees et al., 2004; Burgoyne et al., 2005). Seed ferns declined globally in the Cretaceous concomitant with radiation of the angiosperms (Crane and Lidgard, 1990), and the youngest records of several clades are from the Late Cretaceous (Vakhrameev, 1991; Cleal, 1993; Golovneva, 1998; Cantrill and Poole, 2002).

The ultimate demise of seed ferns has been assumed to coincide with the photosynthesis crisis (Vajda and McLoughlin, 2004) and dramatic changes in climate and ecosystem structure (Lomax et al., 2001; Wilf and Johnson, 2004; Twitchett, 2006) associated with the asteroid impact at Chixculub, Mexico, 65 Ma. However, low-resolution palynological sampling

\footnotetext{
${ }^{1}$ Manuscript received 19 September 2007; revision accepted 15 January 2008. The authors thank S. Forsyth, who found the fossil site, and M. Macphail for palynostratigraphic dating. The work was supported by funding from the Australian Research Council and Swedish Research Council.

${ }^{6}$ Author for correspondence (e-mail: steve.mcloughlin@nrm.se)
}

has indicated that the long-term vegetation change across the Cretaceous-Paleogene (K-Pg) boundary in the Antarctic Peninsula region was modest (Askin and Jacobson, 1996). Furthermore, high-resolution palynological data from New Zealand, although suggesting abrupt vegetation dieback, show lower rates of plant extinction ( $<15 \%$; Vajda et al., 2001, 2002; Vajda and Raine, 2003) than areas closer to the Chicxulub impact site (c. 30\%; Nichols et al., 1986). Hence generalist taxa at high paleolatitudes may have had better chances for surviving the abrupt global environmental perturbations ensuing from the impact.

Here we describe leaf fossils from well-dated early Eocene sediments of Tasmania that are referable to a new species of the long-ranging, putative corystosperm, Komlopteris. The fossils represent the youngest seed-fern remains ever described and highlight the existence of a greater than 50-million-year "ghost lineage" linking the Tasmanian species to the next youngest congeneric fossils.

\section{MATERIALS AND METHODS}

Fossil site-The new fossils are well-preserved foliar compressions recovered from carbonaceous estuarine mudstones in the upper part of the Macquarie Harbor Formation (Pole, 1998; 2007; Carpenter et al., 2007) near Strahan, western Tasmania. This unit contains a fossil flora rich in angiosperms, conifers, cycads and ferns, together with marine dinoflagellates. Both spore-pollen and marine dinoflagellate assemblages from these beds are correlative with the midYpresian or Planktonic Foraminiferal Zone P7 (Carpenter et al., 2007) (early Eocene; 52-51 Ma). At that time Australia was connected to Antarctica through Tasmania, and the Strahan area represented the eastern extent of a long, shallow embayment between these landmasses at about $65^{\circ} \mathrm{S}$ (Veevers et al., 1991).

Fossil preparation-Approximately 10 incomplete compound leaves and detached pinnules were available. Numerous additional cuticle fragments occur dispersed through the semiconsolidated sediment, and many macerated examples were mounted on glass slides for transmitted light microscopy. Macroscopic remains were photographed under low-angle illumination. Cuticle was 
prepared by disaggregation of the sediment in water, then mild oxidation of organic residues with hydrogen peroxide. Treated cuticle was photographed by transmitted light micrography using a Zeiss Axiolab (Jena, Germany) polarizing microscope. Cuticle mounted on aluminum stubs was coated with carbon/ gold to a maximum thickness of $2 \mathrm{~nm}$ and imaged using a Philips XL30 (Eindhoven, Netherlands) field emission gun scanning electron microscope. The most complete macrofossil specimens (illustrated herein) together with cuticular preparations are registered with the Tasmanian Museum and Art Gallery, Hobart (prefixed Z). Supplementary slides and SEM stubs with cuticle derived from these specimens are held in the collections of the University of Adelaide, School of Earth and Environmental Sciences, in addition to the SEM stub with dispersed cuticle registered LO DCS1.

\section{Systematic description-}

Order-Corystospermales

Family_-?Corystospermaceae (Thomas, 1933)

Genus-Komlopteris (Barbacka, 1994)

Species-K. cenozoicus S. McLough., R. J. Carp., G. J. Jord. \& R. S. Hill sp. nov. (Figs. 1-17)

Holotype-Z3572, Tasmanian Museum and Art Gallery, Hobart.

Other specimens-Z3567-Z3571 Tasmanian Museum and Art Gallery, Hobart.

Locality and age-Macquarie Harbor Formation, Lowana Road exposure, Macquarie Harbor, Tasmania, Australia $145^{\circ} 21^{\prime} 30^{\prime \prime} \mathrm{E}$; $42^{\circ} 10^{\prime} 10^{\prime \prime} \mathrm{S}$; late Early Eocene.

Etymology - To highlight the presence of a seed fern in the Cenozoic.

Diagnosis-Komlopteris with narrowly ovate to lanceolate pinnules, entire to slightly lobed margin. Midvein evanescing beyond pinnule midpoint; secondary veins at $<40^{\circ}$, separated by shallow furrow. Stomates mostly distributed on the abaxial leaf surface, sparse on the adaxial surface; variably arranged and orientated between veins. Guard cells deeply sunken; polar extensions to $10 \mu \mathrm{m}$ long; 4-7 subsidiary cells.

Description-Leaves pinnate (all specimens incomplete). Pinnules subopposite, narrowly ovate to lanceolate (Figs. 1-4), 18-82 mm long, 8-24 mm wide; margins entire to slightly lobed (Figs. 5-8); apex acute but rounded (Figs. $1,2)$; base acute, asymmetrical with the acroscopic margin more sharply angled and, at least in distal pinnules, slightly decurrent (Figs. 3, 4). Midvein distinct proximally but evanescent in the distal half of each pinnule (Figs. 2, 4, 8). Most secondary veins departing the midvein at $20^{\circ}-30^{\circ}$ (maximum $40^{\circ}$ ) proximally, becoming more acute $\left(<10^{\circ}\right)$ distally. Secondary veins bifurcating once or twice, gently incurved or recurved; $0.4-1.2 \mathrm{~mm}$ apart (typical density about 7 per $\mathrm{cm}$ along the margin). A shallow longitudinal furrow or ridge is present between each vein; furrows are particularly clear on leaf impressions (Figs. 5,8 ). Stomates scattered between veins; apertures variably orientated (Fig. 13). Guard cells deeply sunken, 10-23 $\mu \mathrm{m}$ long with polar extensions to $10 \mu \mathrm{m}$, generally thinly cutinized, (Figs. 11, 14), surrounded by a single ring of 4-7 trapezoid to oblong subsidiaries $(15-50 \mu \mathrm{m}$ long, $15-20 \mu \mathrm{m}$ wide) thus indicat- ing haplocheilic derivation (Figs. 11, 12). Some guard cells abutted by prominent cuticular ledges or flanges (Figs. 12, 15, 16). Most stomates are separated by several cells; subsidiaries rarely shared between stomates. Stomatal pit surrounded by a thickly cutinized, slightly raised rim (Fig. 10), which in some specimens has been compressed onto the cutinized wall of the stomatal pit to produce a conspicuously thickened ring around the stomate when viewed in transmitted light (Fig. 14). The outer margin of the raised rim in some cases marked by a crease, thickening, or inflection of the periclinal wall of the subsidiary cells on the inner surface of the cuticle (Figs. 15, 16). Cuticle bearing circular thickenings, suggestive of trichome bases or incompletely developed stomates sparsely and irregularly positioned in the intercostal areas (Fig. 17). Epidermal cells mostly oblong to rectangular, 12-25 $\mu \mathrm{m}$ wide, up to $120 \mu \mathrm{m}$ long, generally with straight lateral walls and oblique or wavy end walls, strongly aligned longitudinally over the veins (Fig. 9). Cuticle over the periclinal walls of epidermal cells of uniform thickness, smooth or slightly pitted. Interveinal epidermal cells variable in shape, size, and orientation, with solid or slightly beaded anticlinal wall cuticle (Figs. 11, 13).

\section{DISCUSSION}

Affinities of the fossils-The new Tasmanian fossils can readily be distinguished from conifers, ginkgoaleans, gnetaleans, and angiosperms by their pinnate architecture and lanceolate pinnules with divergent, dichotomous, open venation (Figs. 1-8). The pinnules differ from fern foliage in having robust cuticle with sunken stomates (Figs. 9-14), and bear no resemblance to bryophytes or lycophytes. The fossils have superficial similarities to some cycads, the only other group of extant land plants, but can be discriminated from this group on the basis of a range of characters as follows.

Harris (1964) discussed the difficulties in consistently distinguishing cycadaleans and seed ferns based on fragmentary macrofossils and dispersed cuticle. However, he noted a tendency for seed ferns to have pinnules with decurrent margins and veins that were divergent and twice or more pinnately divided. Among known cycads, Bowenia alone is reminiscent of seed ferns in having bipinnate, superficially fern-like foliage with divergent veins. Coincidentally, well-preserved Bowenia foliage occurs with Komlopteris in the Tasmanian fossil assemblage. However, it is immediately distinguishable from $K$. cenozoicus by its possession of toothed leaf margins and a range of very distinct cuticular features, many of them shared with other cycads. These include the presence of bands of oblique or variably orientated epidermal cells and stomatal complexes that
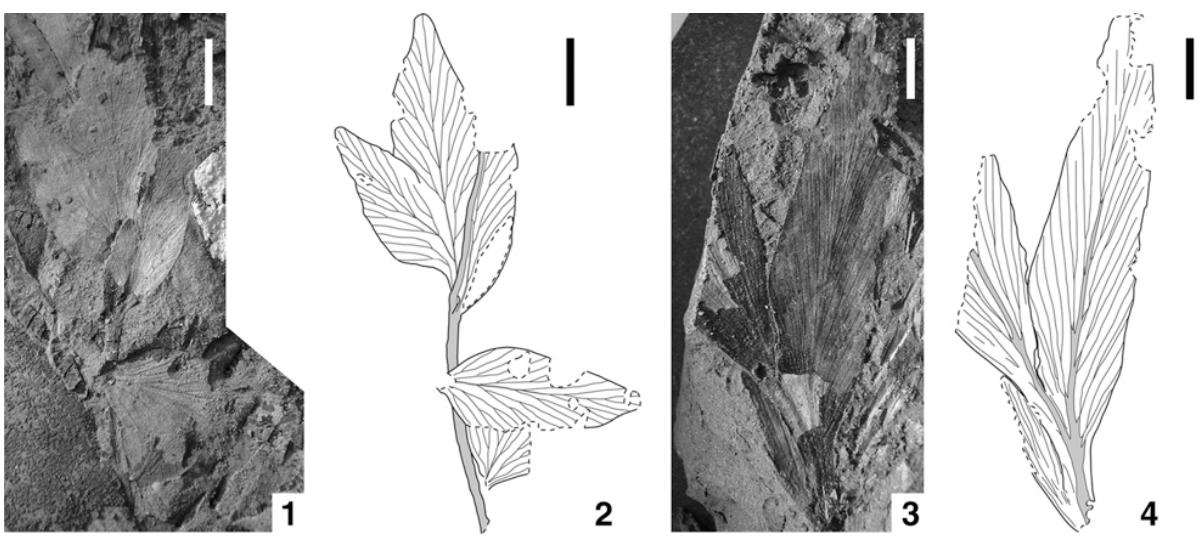

Figs. 1-4. Komlopteris cenozoicus sp. nov., the youngest known seed-fern foliage. 1. Holotype, Z3572, portion of a compound leaf. 2. Line drawing of the holotype showing venation pattern. 3. Attached pinnules with asymmetrical bases, Z3571. 4. Line-drawing of Z3571 showing venation pattern. Scale bars $=10 \mathrm{~mm}$. 

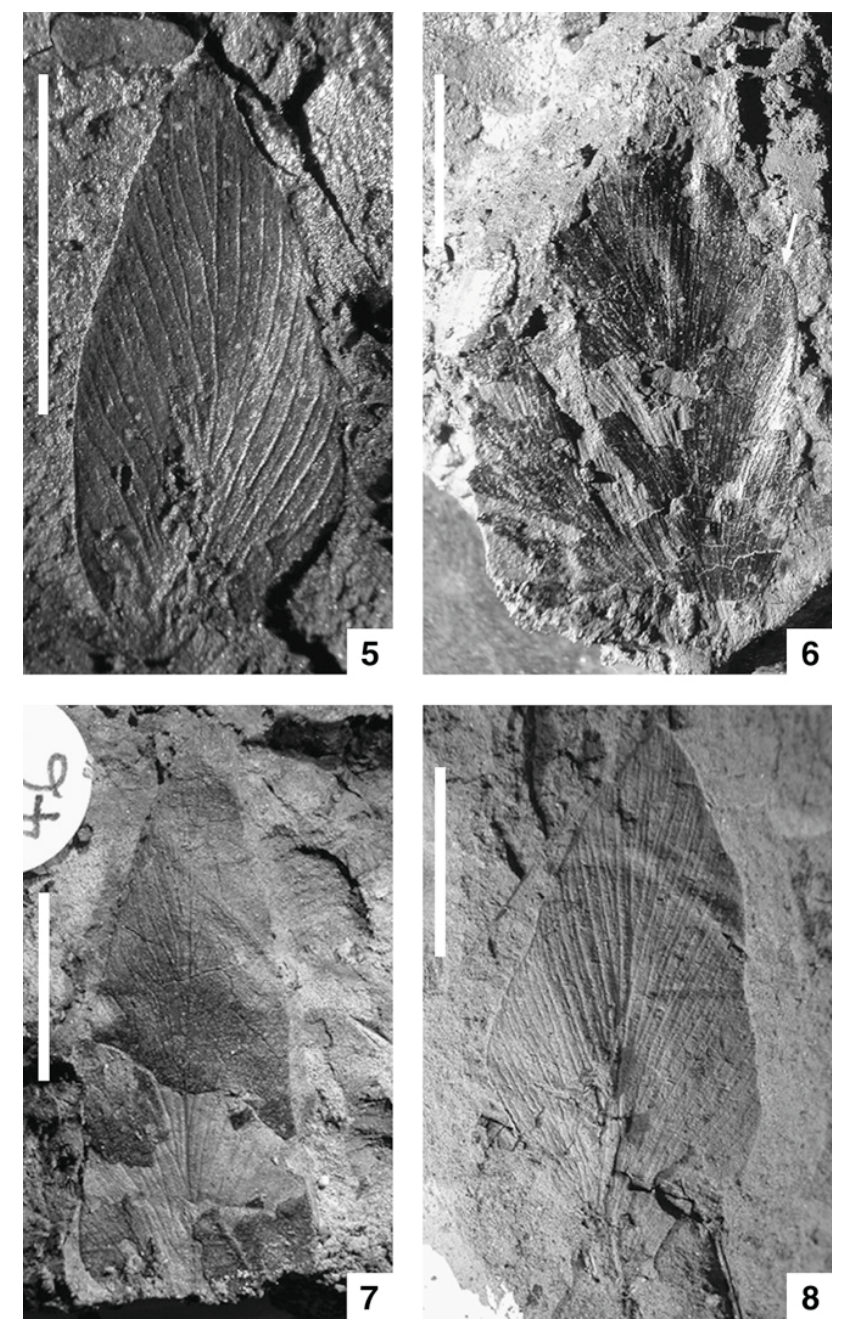

Figs. 5-8. Detached Komlopteris cenozoicus sp. nov. pinnules. 5. Pinnule showing subtle longitudinal depressions between veins, Z3567. 6. Proximal part of pinnule with slight lobing (arrowed), Z3568. 7. Distal part of pinnule with gently tapering apex and entire to slightly wavy margins, Z3569. 8. Pinnule with wavy margins and well-developed interveinal grooves, Z3570. Scale bars $=10 \mathrm{~mm}$.

regularly have bilateral symmetry and that are mostly aligned parallel to the veins (Hill, 1978). Additionally, cycad cuticle is generally characterized by thickenings over the periclinal walls of individual or clustered epidermal cells that stain more darkly than other cells, as shown, for instance, by Greguss (1968) and Hill (1978, 1980). Moreover, cycad pinnules do not possess a midvein giving off secondary veins apart from Stangeria, which has a persistent midvein and high-angle secondary veins. The cuticle morphology of Stangeria also differs from K. cenozoicus by its distinct polar and lateral subsidiary cells and the presence of prominent folds around the stomatal apparatus (Saiki et al., 1991). Related fossils assigned to Eostangeria are distinguished by possession of diamond-shaped epidermal cells and prominent papillae (Kvaček and Manchester, 1999).

The foliar characters of the new Tasmanian fossils conform to those of the seed-fern Komlopteris Barbacka (1994); most striking are the variably lobed pinnules (Figs. 6, 8) with evanescent midveins and gently divergent secondary veins (Figs. 3-5,
7, 8). Komlopteris species were originally assigned to Pachypteris Brongniart (synonymous with Thinnfeldia Ettingshausensee Doludenko et al., 1998) but were differentiated by Barbacka (1994) based on their less-lobed pinnules, the restriction of stomates to intercostal bands, and the appearance of a more or less thickened "line" across the periclinal cuticle of each subsidiary cell to give the impression of a ring around the stomatal pit. This latter feature is not clear on all the specimens illustrated by Barbacka (see, e.g., Barbacka, 1994, pl. V, fig. 2), and in our recognition of the Tasmanian specimens as Komlopteris, we place greater emphasis on the former two diagnostic features of pinnule morphology and stomatal distribution. Nevertheless, although prominent cuticular flanges usually obscure the periclinal cuticle of the subsidiary cells in $K$. cenozoicus, the presence of an inflection or crease in this cuticle can be interpreted in stomates that have been obliquely compressed or viewed from the side (Figs. 15, 16). This could correspond with the "line" reported by Barbacka (1994).

Komlopteris ranges from the Early Jurassic of Europe, the Antarctic Peninsula and possibly east Asia (Zhou, 1981; Barbacka, 1994; Rees and Cleal, 2004), through the Middle and Late Jurassic of Australia (Gould, 1975) and Early Cretaceous of India and Australia (Maheshwari, 1986; McLoughlin et al., 2002). The Tasmanian specimens are particularly similar in shape and venation to $K$. indica (Feistmantel) Barbacka from the Cretaceous of India and Australia. Both the Indian and Australian specimens have deeply sunken stomates and share the prominent darkened ring around stomates when viewed in transmitted light. However, the Tasmanian specimens are here assigned to a new species based on their possession of more acute veins (Figs. 1-8), distinctive interveinal grooves (Figs. 5,8 ), more pronounced polar extensions on the guard cells (Figs. 11, 12) and 4-7 subsidiary cells per stomate (Figs. 11, 14), whereas $K$. indica generally has 5-6 subsidiaries.

The higher-level taxonomy of Komlopteris remains poorly resolved, although Barbacka (1994) inferred a corystospermalean affinity based on similarity of the leaves to European Pachypteris, which are associated with corystospermous microsporangiate fructifications (Kirchner and Müller, 1992). Variably lobed pinnate foliage, gently divergent, dichotomous venation, and sunken, variably orientated stomates are typical corystosperm characters (Anderson and Anderson, 2003), and in the absence of attached reproductive structures, the Tasmanian fossils fit best within the circumscription of that group. Komlopteris is readily distinguished from other seed-fern groups. Thus, Caytoniales have pinnules with reticulate venation, Pentoxylales have taeniopteroid venation and Bennettitales have syndetocheilic (i.e., appearing brachyparacytic) stomatal complexes. Peltaspermales mostly have "rachis pinnules" (zwischenfiedern), strongly papillate cuticle, and most are known from the late Paleozoic and early Mesozoic.

The subtle longitudinal furrow between adjacent veins is diagnostic of the new species. Although the stomates are broadly scattered between veins, they are not narrowly regimented within a discrete stomatal groove (Fig. 14). The furrows may represent evidence of plicate vernation, which is an uncommon feature among nonangiospermous plants, although it has been illustrated for Permian gigantopterids (Glasspool et al., 2004). Very similar furrows in certain fossil Nothofagus leaves have been interpreted as evidence of plicate vernation and deciduousness (Scriven et al., 1995). Dark season deciduousness may have been an adaptation among some plant lineages to the conditions of extreme photoperiod experienced at very high southern 

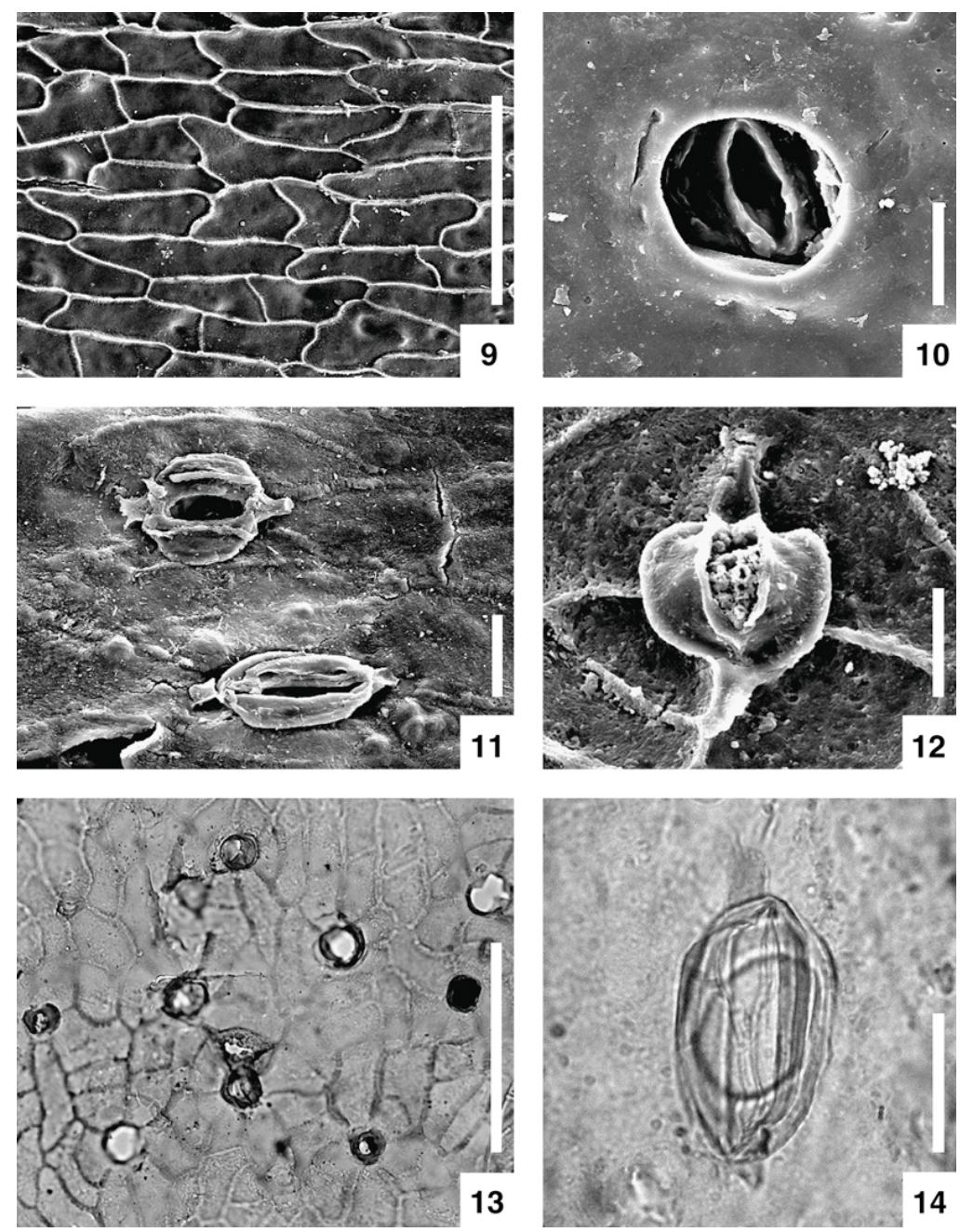

Fig. 9-14. Cuticular details of Komlopteris cenozoicus pinnules. 9. Scanning electron micrograph (SEM) of the interior of the abaxial cuticle over a vein (pinnule axis orientated horizontally on page), LO DCS1. 10. SEM of the exterior of a stomate (abaxial surface) showing a well-developed pit and slightly raised rim, Z3570. 11. SEM of the interior of the abaxial cuticle surface showing two stomates with well-developed lateral ledges and polar extensions, LO DCS1. 12. SEM of the interior of an abaxial stomate showing prominent lateral ledges that support the guard cells on a different level to that of the four surrounding subsidiary cells, Z3567. 13. Light micrograph (LM) of the abaxial cuticle showing irregular arrangement of stomates in the interveinal region (leaf axis orientated vertically on page), Z3567. 14. LM of abaxial stomate showing prominent thickening around stomatal pit, Z3568. Scale bars = $100 \mu \mathrm{m}$ for Figs. 9, 13; $10 \mu \mathrm{m}$ for Figs. 10-12, 14.

latitudes in the Paleogene. It may thus explain the atypical basal abscission zone in leaves of the enigmatic extinct cycad Pterostoma (Hill, 1980), and the predominance of isolated pinnules rather than complete leaves of Komlopteris species.

Indisputable seed-fern pollen has yet to be found in the palynoflora from the sediments in which the Komlopteris foliage was recovered (M. K. Macphail, Consultant Palynological Services, Aranda, Australia, personal communication). However, some small, ill-preserved bisaccate pollen grains in the assemblage might represent Alisporites or Vitreisporites (seed-fern) pollen. Sparse Alisporites grains (Corystospermaceae) have been identified in other southeastern Australian Paleogene sediments (Harris, 1965), but their presence has generally been attributed to reworking from Mesozoic strata.

Seed-fern refugia and surviving the end-Cretaceous extinction event-While gymnosperm diversity as a whole remained relatively stable in Australia through the Cretaceous (Nagalingum et al., 2002), the diversity and relative abundance of seed ferns steadily reduced, matching their global decline (Anderson et al., 1999). Applying the broadest circumscription to the group, the youngest seed-fern macrofossils hitherto recorded from Australia are of bennettitaleans, pentoxylaleans, and possible caytonialeans from the Cenomanian of northeastern Australia (McLoughlin et al., 1995; Pole and Douglas, 1999). However, very few latest Cretaceous and Paleocene Australian plant fossil assemblages have been investigated, allowing the possibility that more "ghost" lineages through the 38 million years between the Cenomanian and Eocene await discovery.

Although the effects of the asteroid impact in Yucatan were global, decreasing levels of environmental perturbation have been reported with increasing distance from the impact site in both hemispheres (Askin and Jacobson 1996; Vajda et al., 2001, 2002; Nichols and Johnson, 2002; Vajda and Raine, 2003). This 

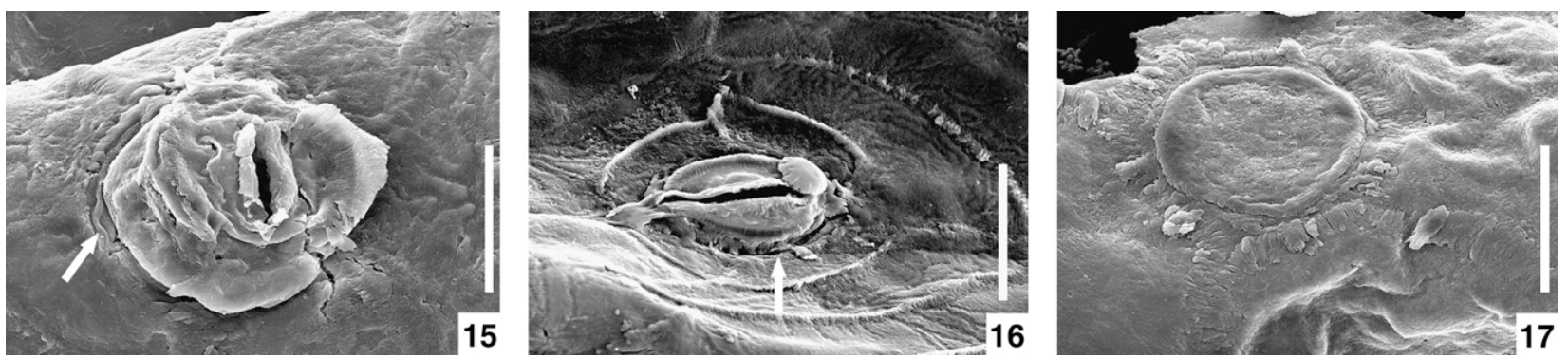

Fig. 15-17. Cuticular details of Komlopteris cenozoicus pinnules. 15. SEM of the interior of a stomate (abaxial surface) showing development of broad ledges flanking the guard cells that partially obscure a crease or inflection (arrow) in the periclinal walls of the subsidiary cells, Z3570. 16. Oblique SEM view of the interior of a stomate (abaxial surface) showing broad cuticular ledges around the guard cells that cover the innermost parts of the subsidiaries. A fungal germling is evident to the right of the stomatal pore. A crease (arrow) in the periclinal walls of the subsidiary cells marks the point at which these cells arch to form a low rim around the stomate in external view (see Fig. 10), LO DCS1. 17. SEM of the cuticle interior showing a low, thickened disk that may represent an incompletely developed stomate or trichome base, Z3570. Scale bars $=20 \mu \mathrm{m}$.

pattern of ecosystem perturbation suggests that high latitude conditions including those prevalent in Tasmania may have provided a refuge allowing some Mesozoic gymnosperms to survive the abrupt global environmental changes and persist into the Cenozoic. Although deciduousness in these plants might be used to argue that the K-Pg crisis initiated during the southern winter (cf. Wolfe, 1991), mesothermal broad-leafed deciduous forests also flourished in the Paleogene of the northern hemisphere (Wolfe, 1987); hence the new fossils provide no definitive evidence for the timing of impact.

On a broader time scale, high latitudes may have provided a refuge for archaic gymnosperms in the face of increasing competition from angiosperms, which initially diversified at low latitudes in the mid-Cretaceous and progressively radiated to higher latitudes later in the period (Crane and Lidgard, 1989, 1990; Drinnan and Crane, 1989). Apart from K. cenozoicus, other fossil evidence highlights the Tasmanian region as a Paleogene refuge for diverse and disparate gymnosperm taxa, including Pterostoma (Hill, 1980; Hill and Pole, 1994), the only Cenozoic record of Ginkgo in Australasia (Hill and Carpenter, 1999), and numerous conifers (Hill and Brodribb, 1999). Some remarkable animal and plant taxa that are presumed to have arisen in the Mesozoic even persist to the present as relictual populations in Tasmania. Of particular note are anaspid crustaceans, Athrotaxis, podocarp conifers including Microcachrys, and representatives of Hydatellaceae (Saarela et al., 2007), the basal lineages of Proteaceae (Weston and Barker, 2006) and Nothofagus.

Seed ferns and some other gymnosperms also persisted longer at northern high latitudes compared to the paleotropics. Vakhrameev $(1981,1991)$ noted the persistence of ginkgoaleans, Phoenicopsis, leptostrobaleans, and bennettitaleans in a range of upland and coastal plain deposits in the Late Cretaceous of the Okhotsk-Chukotka province (far northeastern Russia) beyond their ranges at lower paleolatitudes. Vakhrameev (1991) highlighted the persistence of the extinct gymnosperm Nilssonia to the end of the Cretaceous in northeastern Russia and in the adjacent high-latitude Canadian-Alaskan province (from the Edmonton Group: Bell, 1949). Other records of gymnosperm late survivorship at northern high latitudes include caytonialian seed-ferns (in the Santonian/Campanian of Greenland: Boyd, 1992) and podocarp pollen (in the Miocene of Alaska and Siberia: Reinink-Smith and Leopold, 2005).

Although some of the Tasmanian extinct and extant lineages are phylogenetically isolated and species-poor ("relicts"), evo- lutionary radiation in others (e.g., Araucariaceae, Proteaceae) probably occurred after the K-Pg event. Moreover, the tempo of speciation appears to be higher in temperate vs. tropical regions in birds and mammals (Weir and Schluter, 2007). Thus, highlatitude regions provide both important biological refugia and potentially crucial sources of postdisaster evolutionary radiations. The survival of many taxa in Tasmania beyond their temporal ranges in other parts of Gondwana may have been facilitated by the persistence of humid climates well after the disappearance of such conditions in most other regions.

Significantly, New Zealand and the formerly connected island of New Caledonia, which endured even greater mid- to high-latitude isolation than Tasmania through the Cenozoic, also host fossil and extant relictual taxa denoting the existence of early Cenozoic ghost lineages. These include Amborella in New Caledonia (considered to be the sole representative of the lineage that is sister to all other angiosperms: Soltis et al., 1999), and in New Zealand the extant tuataras (Sphenodon spp.), New Zealand wrens (Ericson et al., 2002), Hydatellaceae (Saarela et al., 2007) and an extinct archaic mammal recently discovered from Miocene sediments (Worthy et al., 2006).

The Kerguelen Plateau at $50^{\circ}-60^{\circ} \mathrm{S}$ represents another possible refugium for Mesozoic gymnosperms. Dispersed Alisporites and Vitreisporites (seed-fern pollen) are consistent elements of Kerguelen Plateau palynofloras until at least the Santonian (Mohr and Gee, 1992). Younger Cretaceous and Paleogene sediments occur on the plateau but have not been investigated for terrestrial palynomorphs (Mao and Mohr, 1992). Marine inundation of most of the Kerguelen Plateau in the Santonian and Campanian is likely to have been the main impediment to survival of Mesozoic plants, but the presence of younger Araucariaceae and Cupressaceae fossil wood on Kerguelen Island suggest that at least some woody vegetation of Gondwanan affinity survived on this isolated continental fragment until the Pleistocene (Philippe et al., 1998).

Thus, rather than being casualties of the K-Pg mass extinction, the demise of many typical "Mesozoic taxa" (including Komlopteris cenozoicus) in southern middle to high latitudes may have been linked to the development of the circum-Antarctic current in the mid-Cenozoic (Shackleton and Kennett, 1975; Zachos et al., 1994), and one or a combination of its consequent environmental changes: pronounced global cooling and, especially in Australia (which moved rapidly into lower latitudes), aridification and markedly altered photoperiods (Macphail et al., 1994). 


\section{LITERATURE CITED}

Anderson, J. M., AND H. M. Anderson. 2003. Heyday of the gymnosperms: Systematics and biodiversity of the Late Triassic Molteno fructifications. Strelitzia 15, National Botanical Institute, Pretoria, South Africa.

Anderson, J. M., H. M. Anderson, S. Archangelsky, M. Bamford, S. Chandra, M. Dettmann, R. Hill, S. Mcloughlin, and O. RöSLER. 1999. Journal of African Earth Sciences 28: 145-167.

Askin, R. A., AND S. R. JACOBSON. 1996. Palynological change across the Cretaceous-Tertiary boundary on Seymour Island, Antarctica: Environmental and depositional factors. In N. MacLeod and G. Keller [eds.], Cretaceous-Tertiary mass extinctions: Biotic and environmental changes, 7-25. Norton \& Co, London, UK.

BARBACKA, M. 1994. Komlopteris Barbacka, gen. nov., a segregate from Pachypteris Brongniart. Review of Palaeobotany and Palynology 83: 339-349.

Bell, W. A. 1949. Uppermost Cretaceous and Paleocene floras of western Alberta. Canada Department of Mines and Resources Geological Survey Bulletin 13: 1-231.

Boyd, A. 1992. Revision of the Late Cretaceous Pautût flora from West Greenland: Gymnospermopsida (Cycadales, Cycadeoidales, Caytoniales, Ginkgoales, Coniferales). Palaeontographica 225B: 105-172.

Burgoyne, P. M., A. E. van Wyk, J. M. Anderson, And B. D. Schrire. 2005. Phanerozoic evolution of plants on the African plate. Journal of African Earth Sciences 43: 13-52.

Cantrill, D. J., AND I. Poole. 2002. Cretaceous patterns of floristic change in the Antarctic Peninsula. In J. A. Crame and A. W. Owen [eds.], Palaeobiogeography and biodiversity change: The Ordovician and Mesozoic-Cenozoic radiations, 141-152. Geological Society, London, UK.

Carpenter, R. J., G. J. Jordan, and R. S. Hill. 2007. A toothed Lauraceae leaf from the Early Eocene of Tasmania, Australia. International Journal of Plant Sciences 168: 1191-1198.

Crane, P. R., And S. Lidgard. 1989. Angiosperm diversification and paleolatitudinal gradients in Cretaceous floristic diversity. Science 246: 675-678.

Crane, P. R., and S. Lidgard. 1990. Angiosperm radiation and patterns of Cretaceous palynological diversity. In P. D. Taylor and G. P. Larwood [eds.], Major evolutionary radiations. Systematics Association Special Volume 42: 377-407.

Cleal, C. J. 1993. Gymnospermophyta. In M. J. Benton [ed.], The fossil record 2, 795-808. Chapman and Hall, London, UK.

Doludenko, M. P., E. I. Kostina, And V. A. SAmylina. 1998. A reconsideration of Pachypteris Brongniart and Thinnfeldia Ettingshausen. Palaeontographica 247B: 55-64.

Doyle, J. A. 2006. Seed ferns and the origin of angiosperms. Journal of the Torrey Botanical Society 133: 169-209.

Drinnan, A. N., AND P. R. CRANE. 1989. Cretaceous paleobotany and its bearing on the biogeography of austral angiosperms. In T. N. Taylor and E. L. Taylor [eds.], Antarctic paleobiology: Its role in the reconstruction of Gondwana, 192-219. Springer-Verlag, New York, New York, USA.

Ericson, P. G. P., L. Christidis, A. Cooper, M. Irestedt, J. Jackson, U. S. Johansson, And J. A. Norman. 2002. A Gondwanan origin of passerine birds supported by DNA sequences of the endemic New Zealand wrens. Proceedings of the Royal Society of London, B, Biological Sciences 269: 235-241.

Glasspool, I. J., J. Hilton, M. E. Collinson, Shi-Jun Wang, AND LiCheng-SEn. 2004. Foliar physiognomy in Cathaysian gigantopterids and the potential to track Palaeozoic climates using an extinct plant group. Palaeogeography, Palaeoclimatology, Palaeoecology 205: 69-110.

Greguss, P. 1968. Xylotomy of the living cycads. Akadémiai Kiadó, Budapest, Hungary.

Golovneva, L. B. 1998. Cretaceous floral evolution in northeastern Russia. Paleontological Journal 32: 633-641.

Gould, R. E. 1975. The succession of Australian pre-Tertiary megafossil floras. Botanical Review 41: 453-483.
Harris, T. M. 1964. The Yorkshire Jurassic flora II. Caytoniales, Cycadales, and pteridosperms. British Museum (Natural History), London, UK

HARRIS, W. K. 1965. Basal Tertiary microflora from the Princetown area, Victoria, Australia. Palaeontographica 115B: 75-106.

Hill, R. S. 1978. Two new species of Bowenia Hook. ex Hook. f. from the Eocene of eastern Australia. Australian Journal of Botany 26: 837-846.

Hill, R. S. 1980. Three new Eocene cycads from Eastern Australia. Australian Journal of Botany 28: 105-122.

Hill, R. S., AND T. J. BrodriBB. 1999. Turner review no. 2: Southern conifers in time and space. Australian Journal of Botany 47: 639-696.

Hill, R. S., And R. J. Carpenter. 1999. Ginkgo leaves from Paleogene sediments in Tasmania. Australian Journal of Botany 47: 717-724.

Hill, R. S., AND M. S. Pole. 1994. Two new species of Pterostoma R.S. Hill from Cenozoic sediments in Australia. Review of Palaeobotany and Palynology 80: 123-130.

KirChNer, M., AND A. Müller. 1992. Umkomasia franconica n. sp. und Pteruchus septentrionalis n. sp., Fruktifikationen von Thinnfeldia Ettinghausen. Palaeontographica 224B: 63-73.

KVAČEK, Z., AND S. R. MANCHESTER. 1999. Eostangeria Barthel (extinct Cycadales) from the Paleogene of western North America and Europe. International Journal of Plant Sciences 160: 621-629.

Lomax, B., D. BeErling, G. UPChurch, And B. OtTo-Bliesner. 2001. Rapid (10-yr) recovery of terrestrial productivity in a simulation study of the terminal Cretaceous impact event. Earth and Planetary Science Letters 192: 137-144.

Maheshwari, H. K. 1986. Thinnfeldia indica Feistmantel and associated plant fossils from Tiruchirapalli District, Tamil Nadu. Palaeobotanist 35: 13-21.

Macphail, M. K., N. Alley, E. M. Truswell, and I. R. K. Sluiter. 1994. Early Tertiary vegetation: Evidence from spores and pollen. In R. S. Hill [ed.], History of the Australian vegetation: Cretaceous to Recent, 189-262. Cambridge University Press, Cambridge, UK.

Mao, S.-Z., ANd B. A. R. Mohr. 1992. A Campanian to Maestrichtian dinocyst flora from the Kerguelen Plateau, southern Indian Ocean (ODP Leg 120). In S. W. Wise, R. Schlich, et al. [eds.], Proceedings of the Ocean Drilling Program, Scientific Results 120(1): 307-341. College Station, Texas, USA.

McLoughlin,S.,A.N.Drinnan,AndA.C.RozefElds.1995. ACenomanian flora from the Winton Formation, Eromanga Basin, Queensland, Australia. Memoirs of the Queensland Museum 38: 273-313.

McLoughlin, S., A.-M. Tosolini, N. Nagalingum, And A. N. Drinnan. 2002. The Early Cretaceous (Neocomian) flora and fauna of the lower Strzelecki Group, Gippsland Basin, Victoria, Australia. Association of Australasian Palaeontologists Memoirs 26: 1-144.

Mohr, B., AND C. T. GEE. 1992. Late Cretaceous palynofloras (sporomorphs and dinocysts) from the Kerguelen Plateau, Southern Indian Ocean (Sites 748 and 750). In S. W. Wise, R. Schlich, et al. [eds.], Proceedings of the Ocean Drilling Program, Scientific Results 120(1): 281-306. College Station, Texas, USA.

Nagalingum, N. S., A. N. Drinnan, R. Lupia, and S. McLoughlin. 2002. Fern spore diversity and abundance in Australia during the Cretaceous. Review of Palaeobotany and Palynology 119: 69-92.

Nichols,D.J.,D.M.Jarzen,C.J.Orth,ANDP.Q.OLIVER.1986. Palynological and iridium anomalies at Cretaceous-Tertiary Boundary, south-central Saskatchewan (Canada). Science 231: 714-717.

Nichols, D. J., AND K. R. Johnson. 2002. Palynology and microstratigraphy of Cretaceous-Tertiary boundary sections in southwestern North Dakota. Geological Society of America, Special Papers 361: 95-143.

Philippe, M., A. Giret, AND G. J. Jordan. 1998. Tertiary and Quaternary fossil wood from Kerguelen (southern Indian Ocean). Comptes Rendus de l'Acadamie de Sciences, Series IIA, Earth and Planetary Science 326: 901-906.

Pole, M. 1998. Early Eocene estuary at Strahan, Tasmania. Australian Journal of Earth Sciences 45: 979-985.

Pole, M. 2007. Early Eocene dispersed cuticles and mangrove to rainforest vegetation at Stahan-Regatta Point, Tasmania. Palaeontologia Electronica 10 (3): 15A: 66pp. 
Pole, M. S., And J. G. Douglas. 1999. Bennettitales, Cycadales and Ginkgoales from the mid Cretaceous of the Eromanga Basin, Queensland, Australia. Cretaceous Research 20: 523-538.

ReEs, P. M., AND C. J. Cleal. 2004. Early Jurassic floras from Hope Bay and Botany Bay, Antarctica. Special Papers in Palaeontology 72: 1-90.

Rees, P., C. R. Noto, J. M. Parrish, and J. T. PArrish. 2004. Late Jurassic climates, vegetation, and dinosaur distributions. Journal of Geology 112: 643-653.

Reinink-Smith, L. M., AND E. B. LeOPOLD. 2005. Warm climate in the late Miocene of the south coast of Alaska and the occurrence of Podocarpaceae pollen. Palynology 29: 205-262.

Saarela, J. M., H. S. Rai, J. A. Doyle, P. K. Endress, S. Matthews, A. D. Marchant, B. G. Briggs, and S. W. Graham. 2007. Hydatellaceae identified as a new branch near the base of the angiosperm phylogenetic tree. Nature 446: 312-315.

SAIKI, K., T. Kimura, AND J. HoriUchi. 1991. Stenopteris cyclostoma Saiki, Kimura et Horiuchi sp. nov. (possible pteridosperm), from the Lower Cretaceous Choshi Group, in the Outer Zone of Japan. Transactions and Proceedings of the Palaeontological Society of Japan 164: 964-972.

Scriven, L. J., S. McLoughlin, And R. S. Hill. 1995. Nothofagus plicata (Nothofagaceae), a new deciduous Eocene macrofossil species, from southern continental Australia. Review of Palaeobotany and Palynology 86: 199-209.

Shackleton, N. J., AND J.P. KenNetT. 1975. Palaeotemperature history of the Cenozoic and the initiation of Antarctic glaciation: Oxygen and carbon isotope analysis in DSDP sites 277, 279, 281. Initial Report of the Deep Sea Drilling Project 29: 743-755.

Soltis, P. M., D. E. Soltis, And M. W. Chase. 1999. Angiosperm phylogeny inferred from multiple genes as a tool for comparative biology. Nature 402: 402-404.

Thomas, H. H. 1933. On some pteridospermous plants from the Mesozoic rocks of South Africa. Philosophical Transactions of the Royal Society of London, A 222B: 193-265.

TwitchetT, R. J. 2006. The palaeoclimatology, palaeoecology and palaeoenvironmental analysis of mass extinction events. Palaeogeography, Palaeoclimatology, Palaeoecology 232: 190-213.

VAJdA, V., AND S. McLoughlin. 2004. Fungal proliferation at the Cretaceous-Tertiary boundary. Science 303: 1489.

VAJDA, V., AND J. I. RAINE. 2003. Pollen and spores in marine Cretaceous/ Tertiary boundary sediments at mid-Waipara River, North Canterbury,
New Zealand. New Zealand Journal of Geology and Geophysics 46: 255-273.

VAJDA, V., J. I. RAINE, AND C. J. Hollis. 2001. Indication of global deforestation at the Cretaceous-Tertiary boundary by New Zealand fern spike. Science 294: 1700-1702.

VAjda, V., J. I. Raine, C. J.Hollis, and C.P.STrong. 2002. Global effects of the Chicxulub asteroid impact on terrestrial vegetation: Review of the palynological record from New Zealand Cretaceous/Tertiary boundary. In P. Claeys [ed.], Impact studies, 57-73. Springer-Verlag, Berlin, Germany.

VAKhrameEv, V. A. 1981. Development of floras in the middle part of the Cretaceous period, and older angiosperms. Paleontologicheskii Zhurnal 2: 3-14 (in Russian).

VAKHRAMEEV, V. A. 1991. Jurassic and Cretaceous floras and climates of the Earth. Cambridge University Press, Cambridge, U.K.

Veevers, J.J., C. McA.Powell, AndS.R. Roots. 1991. Review of seafloor spreading around Australia. I. synthesis of the patterns of spreading. Australian Journal of Earth Sciences 38: 373-389.

Weir, J. T., AND D. Schluter. 2007. The latitudinal gradient in recent speciation and extinction rates of birds and mammals. Science 315: 1574-1576.

Weston, P. H., AND N. P. Barker. 2006. A new generic classification of the Proteaceae with an annotated checklist of genera. Telopea 11: 314-344.

Wilf, P., And K. R. Johnson. 2004. Land plant extinction at the end of the Cretaceous: A quantitative analysis of the North Dakota megafloral record. Paleobiology 30: 347-368.

Wolfe, J. A. 1987. Late Cretaceous-Cenozoic history of deciduousness and the terminal Cretaceous event. Paleobiology 13: 215-226.

Wolfe, J. A. 1991. Palaeobotanical evidence for a June 'impact winter' at the Cretaceous/Tertiary boundary. Nature 352: 420-423.

Worthy, T. H., A. J. D. Tennyson, M. Archer, A. M. Musser, S. J. Hand, C. Jones, B. J. Douglas, J. A. McNamara, And R. M. D. Beck. 2006. Miocene mammal reveals a Mesozoic ghost lineage on insular New Zealand, southwest Pacific. Proceedings of the National Academy of Sciences, USA 103: 19419-19423.

Zachos, J. C., L. D. Stott, and K. C. Lohmann. 1994. Evolution of early Cenozoic marine temperatures. Paleoceanography 9: 353-387.

Zhou, Z.-Y. 1981. Some Late Triassic and Early Jurassic pteridosperms from Hunan. Acta Palaeontologica Sinica 20: 15-30. 